\title{
Comparison of phosphate fertilisers in a grazed hill country pasture
}

\section{A.D. Mackay}

Grasslands Division, DSIR

Private Bag, Palmerston North

ABSTRACT A grazing trial evaluated the agronomic effectiveness of 3 different types of phosphate (P) fertilisers. The same fertilisers were also evaluated in a small-plot mowing trial located within the grazing trial. In the grazing trial, which covered 35 ha of summer moist hill country, the partially acidulated phosphate rock (PAPR) and reactive phosphate rock (RPR) were as effective as superphosphate in stimulating legume and pasture production in the first year. In the second year the two slow-release materials continued to perform as well as SSP. In contrast in the mowing trial, superphosphate was more effective than RPR in the first year. This trial technique clearly underestimates the initial effectivness of PAPR and RPR in grazed hill country. The traditional small-plot mowing trial technique, and the role of PAPR and RPR fertilisers in hill country, both need re-evaluation.

Keywords hill country, superphosphate, slow release fertilisers, mowing trials, grazed pasture

\section{INTRODUCTION}

Most phosphate (P) fertiliser used in New Zealand is still based on single superphosphate (SSP). Tonnages sold of a SSP: reactive phosphate rock (RPR) physical mix, commercially known as 'longlife' or 'longerlife' are increasing. The other partially processed or acidulated phosphate fertiliser gaining increasing market share is manufactured by partially acidulating a RPR with phosphoric acid. These are known commercially as PAPRs. Both these partially acidulated $\mathrm{P}$ fertilisers (SSP: RPR and PAPR) contain approximately $50 \%$ of total $\mathrm{P}$ in a water-soluble form and $50 \%$ in a slow-release form. The direct application of RPR, another alternative to SSP, is also gaining increasing acceptance

Established on flat sites, small-plot mowing trials, in which a proportion of the clippings are returned to simulate animal returns, is the traditonal and accepted approach used to evaluate fertiliser materials. Present thinking on the agronomic effectiveness of PAPRbased fertilisers (Rajan \& Quin 1985; Rajan et al. 1987; Mackay \& Wewala 1988) and RPR (Mackay et al. 1984; Quin et al. 1987; Gregg et al. 1988) is based on the findings of such trials. The limitations of small-plot mowing trials for evaluating fertilisers for use in grazed hill country have long been recognised, but are often ignored (Mackay \& Syers 1985). Now that both partially acidulated and RPR are available, a complete investigation of their effectiveness under grazing is warranted.

This study evaluates the agronomic effectiveness of SSP, PAPR and RPR in a grazed pasture and compares their effectiveness in grazed pasture with their performance in a small-plot mowing trial.

\section{MATERIALS AND METHODS}

\section{Location and site description}

The grazing trial at the Hill Country Research Station of Grasslands Division, DSIR near Woodville, covered 35 ha of rolling and steep sedimentary soils derived from siltstones and sandstones with a low phosphate retention $(<30 \%)$, Olsen $P$ of $11.5 \mathrm{mg} / \mathrm{kg}$ of soil and a $\mathbf{p H}$ of 5.2. Annual rainfall is $1300 \mathrm{~mm}$. The site had been in permanent pasture for 10 years and had received moderate dressings of superphosphate over that period.

\section{Fertiliser materials}

SSP, made from a Christmas: Nauru Island phosphate rock mix, had a total $\mathrm{P}$ of $9.1 \%$ of which $86 \%$ was soluble in $2 \%$ citric acid.

PAPR, (commercially known as 'Hyphos') made by the partial acidulation of North Carolina phosphate rock (NCPR) with phosphoric acid, had a total $\mathrm{P}$ of $15.8 \%$ of which $51 \%$ was water soluble.

RPR unground, as received 'North Carolina phosphate rock (NCPR)', had a total P of $12.9 \%$ of which $32 \%$ was soluble in $2 \%$ citric acid.

\section{Experimental design and treatments}

Grazing trial The $3 \mathrm{P}$ fertilisers (SSP, PAPR and RPR) were applied at $35 \mathrm{~kg}$ P/ha. A control (no added P) made up the 4 fertiliser treatments, each replicated twice.

Mowing trial In each plot of the grazing trial a traditional mowing trial was established on a flat site $\left(<5^{\circ}\right)$. Bach fettiliser (SSP, PAPR, RPR) was applied at $35 \mathrm{~kg} \mathrm{P} / \mathrm{ha}$.

\section{Establishment of grazing and mowing trials}

Both the grazing and mowing trials were established in June 1987. All treatments were reapplied at the same rate in December 1988. 
Grazing trial The entire grazing trial was topdressed with $30 \mathrm{~kg} \mathrm{~S} / \mathrm{ha}$ as screened elemental S before the 3 P fertilisers were applied. To ensure an even spread, the SSP, PAPR and NCPR were applied by helicopter in 2 runs.

Mowing trial Fertilisers were applied by hand to pretrimmed plots $(2 \mathrm{~m} \times 2.5 \mathrm{~m})$.

\section{Measurement of pasture and legume production and $\mathbf{P}$ uptake}

Grazing trial Pasture production was measured on 3 slope classes, flat $\left(0-10^{\circ}\right)$, moderate $\left(11-25^{\circ}\right)$ and steep $\left(>25^{\circ}\right)$, and 2 aspects, north west and north east in each fertiliser treatment, giving a total of 48 measurement sites. Pasture production at each site was measured with exclusion cages. Legume content and production were also measured at each harvest, as were the $\mathrm{P}$ and $\mathrm{N}$ contents in a mixed pasture sample. A total of 7 harvests were taken in year one, 6 in year two

Mowing trial At each harvest, which coincided with each harvest of the grazing trial, pasture production was assessed by cutting a $0.6 \mathrm{~m}$ x $1.7 \mathrm{~m}$ strip from each plot. Legume content and production and $\mathrm{P}$ and $\mathrm{N}$ content and $\mathrm{P}$ and $\mathrm{N}$ uptake by pasture, respectively, were also measured at each harvest. Approximately $60 \%$ of clippings were returned to each plot. Animals were excluded from the mowing trials.

\section{Soil sampling and analysis}

Five soil samples to a depth of $75 \mathrm{~mm}$ were taken from each frame site in the grazing trial and from each mowing trial before fertiliser was applied in May 1987, in March 1988 and 1989. After air drying, soil was sieved through $2 \mathrm{~mm}$ and $\mathrm{pH}$ in water, and Olsen $\mathrm{P}$ (Olsen et al. 1954) and Bray P (Bray \& Kurtz 1945) were determined.

\section{Statistical analysis}

All data were subjected to an analysis of variance, LSD values were used to compare treatment means.

\section{RESULTS AND DISCUSSION}

\section{Comparison of mowing and grazing in year 1}

Mowing trial Pasture response to applied $\mathrm{P}$ was significant $(\mathrm{P}<0.01)$ in the first harvest, 10 weeks' after application. SSP increased pasture production much more than RPR. Phosphorus uptake by pasture was also higher. This difference persisted throughout year 1 with annual pasture production from SSP greater than that of the RPR (Figure la). This finding is in agreement with the bulk of published mowing trial studies (Quin et al. 1987) comparing the effectiveness of these fertiliser materials in the year of application. No diffemce in $\mathrm{P}$ uptake by pasture was found between the fertilisers in the first year (Figure 2a), despite differences in initial harvests. Olsen $\mathrm{P}$ values in the mowing trials averaged $22 \mathrm{mg} / \mathrm{kg}$ in March 1988 (Table 1).

Grazing trial Pasture and legume responses $(\mathrm{P}<0.01)$ to applied fertiliser $\mathrm{P}$ were restricted to moderate and steep slopes (Figure lb) where Olsen $P$ values were 12 and $8 \mathrm{mg} / \mathrm{kg}$, respectively (Table 1). Olsen $P$ on the camp sites averaged $38 \mathrm{mg} / \mathrm{kg}$ at the start of the study in May 1987. No differences in either legume or total pasture production were found between the 3 fertilisers on the flat and moderate slopes in year 1 (Figure lb). On steep slopes PAPR and RPR were more effective than SSP. Even in initial harvests of the first year, SSP was not superior to either of these slow-release fertilisers. This finding is completely at odds with the conclusion drawn from the mowing trial in year 1, where SSP was superior to RPR (Figure la).

No differences in $\mathrm{P}$ uptake by pasture were found between the 3 fertilisers on any one of the 3 slope classes in year one (Figure 2a). Both the PAPR and RPR increased $\mathrm{N}$ uptake by pasture on steep slopes (Figure 2b), indirectly by increasing legume growth. In the long-term the increased $\mathrm{N}$ fixation should not only improve the $\mathrm{N}$ economy of the pasture on steep slopes, but also the $\mathrm{N}$ economy of moderate sloping and flat areas as a result of $\mathrm{N}$ transfer in dung and urine.

Little or no change in Olsen $\mathrm{P}$ values was found on moderate and steep slope, 10 months after fertiliser

Table 1 Olsen and Bray P values (mg/kg of soil) from the grazing the mowing trial in March 1988 and 1989.

\begin{tabular}{|c|c|c|c|c|c|c|c|c|}
\hline \multirow{3}{*}{$\begin{array}{l}\text { Fertiliser } \\
\text { treatment }\end{array}$} & \multicolumn{4}{|c|}{1988} & \multicolumn{4}{|c|}{1989} \\
\hline & \multirow[t]{2}{*}{ Mowing } & \multicolumn{3}{|c|}{ Grazing } & \multirow[t]{2}{*}{ Mowing } & \multicolumn{3}{|c|}{ Grazing } \\
\hline & & Flat & Mod. & Steep & & Flat & Mod. & Steep \\
\hline Control & $19(31)$ & $49(89)$ & $12(14)$ & $8(11)$ & $15(27)$ & $25(71)$ & $6(13)$ & $5(12)$ \\
\hline SSP & $15(26)$ & $34(42)$ & $11(15)$ & $7(9)$ & $16(30)$ & $26(61)$ & $11(16)$ & $9(19)$ \\
\hline PAPR & $22(34)$ & $63(77)$ & $12(13)$ & $9(14)$ & $17(33)$ & $40(94)$ & $9(18)$ & $8(15)$ \\
\hline RPR & $15(20)$ & $40(61)$ & $14(17)$ & $7(12)$ & $15(28)$ & $20(57)$ & $11(21)$ & $7(16)$ \\
\hline
\end{tabular}

Bray $\mathrm{P}$ values are in brackets. 
application (Table 1). Soil $\mathrm{pH}$ did increase from 4.9 in May 1987 to 5.2 in March 1988. The Bray removed more $\mathrm{P}$ than the Olsen test from all sites, but did not reflect the differences between fertilisers.

\section{Comparison of mowing and grazing in year 2}

Second year production represents the combined effect of the residual performance of each fertiliser applied in June 1987 and the initial effectiveness of these fertilisers re-applied in December 1988.
M owing trial No pasture or legume response to applied $\mathrm{P}$ was measured in the mowing trial in year two (Figure 3a). The sward in the mowing trials has changed from one of mixed ryegrass (Lolium perenne L.), browntop (Agrostis capillaris L.), sweet vernal (Anthoxanthum odoratum), crested dogstail (Cynosurus cristatus L.) with minor contributions from cocksfoot (Dactylis glomerata) and Yorkshire fog (Holcus lanatus L.), to a sward in which cocksfoot, Yorkshire fog and ryegrass are the dominant grass species. These grass species are favoured under lax, infrequent cutting.

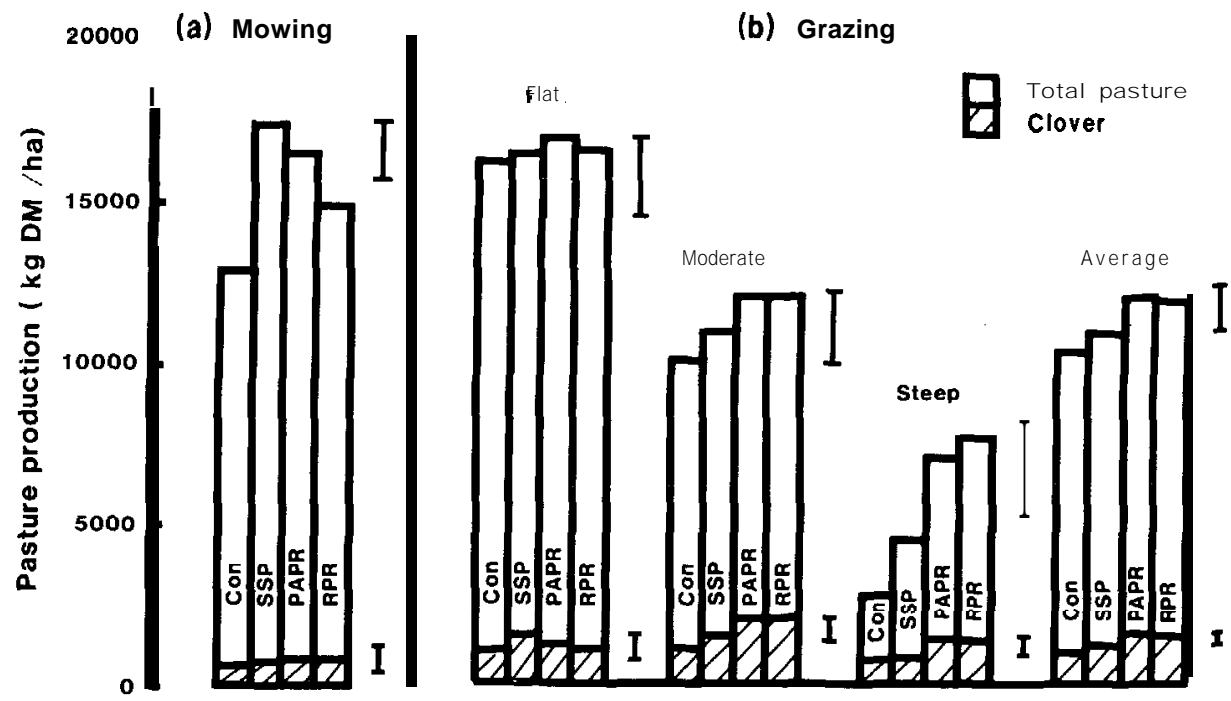

Figure 1 Pasture and legume response to SSP, PAPR and RPR under (a) mowing and (b) grazing in year $1 . \quad$ Vertical bars are LSD values at the $5 \%$ level.
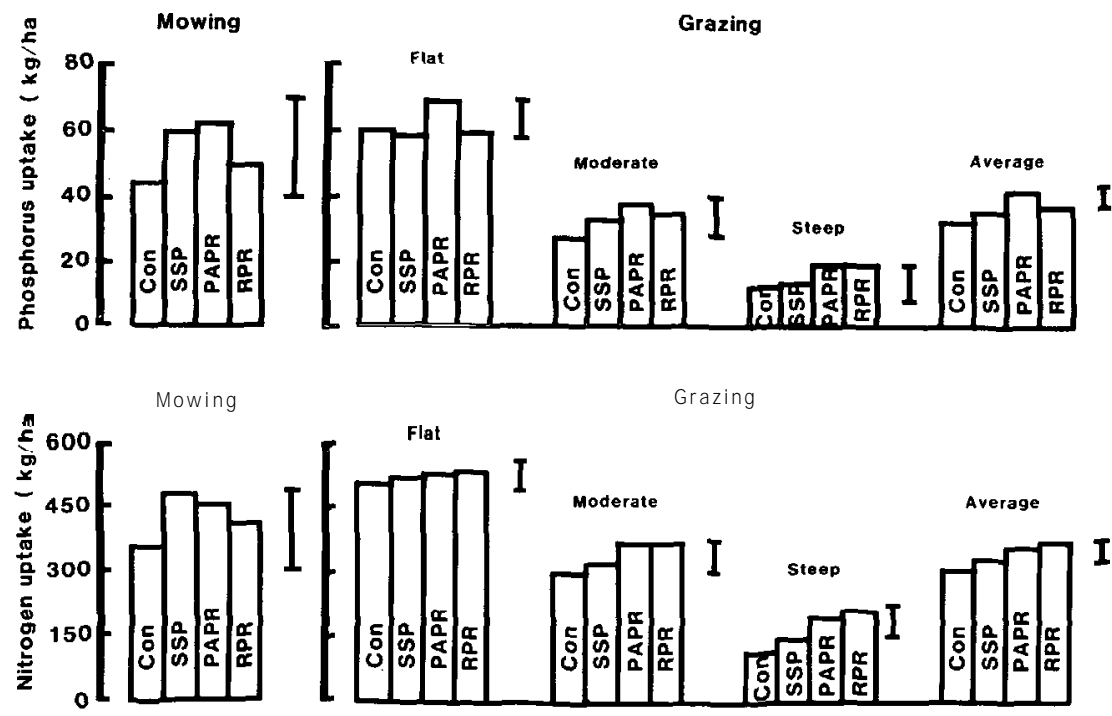

Figure 2 Effect of SSP, PAPR and RPR on (a) phosphorus and (b) nitrogen uptake by pasture in the mowing and grazing trials Vertical bars are LSD values at the $5 \%$ level. 
(a) Mowing

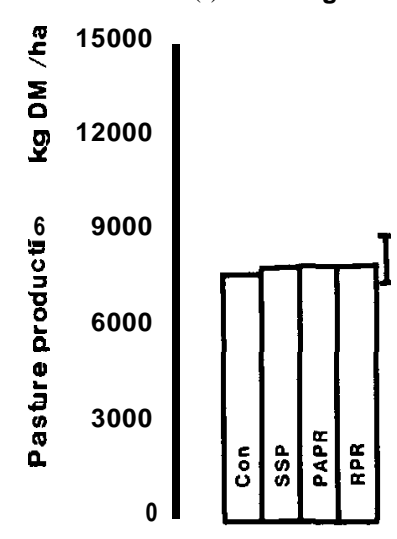

(b) Grazing

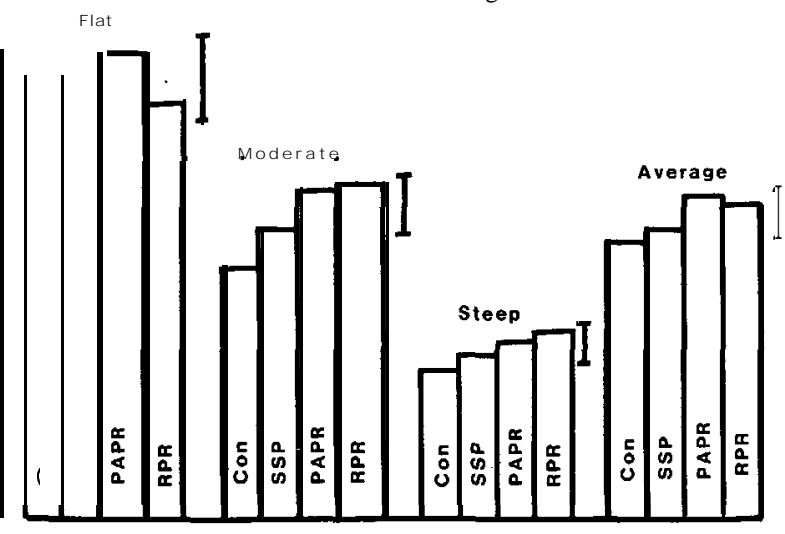

Figure 3 Pasture and legume response to SSP, PAPR and RPR under (a) mowing and (b) grazing in year $2 . \quad$ Vertical bars arc LSD values at the $5 \%$ level.

Grazing trial Pasture and legume response to applied fertiliser $\mathrm{P}$ was significant $(\mathrm{P}<0.01)$ in year 2 (Figure 3). As in year 1 the response was restricted to moderate and steep slopes. No difference in either legume or pasture production was found between the 3 fertilisers, although both the slow release fertilisers again appear to be more effective than SSP on moderate and steep slopes. Flat sites remained unresponsive to all three fertilisers. The decline in Olsen $\mathrm{P}$ values on the moderate and steep slopes of the control paddocks from March 1988 to 1989 (Table 1) reflects the continuing response of the site to added fertiliser. All 3 fertilisers maintained Olsen $P$ values on these 2 slopes at March 1988 levels.

\section{CONCLUSIONS}

Both the PAPR and RPR were more effective as phosphate fertilisers under grazing than might be expected from other published studies, which have all compared these two materials with SSP in small-plot mowing trials. This field trial technique clearly underestimates the effectiveness of the partially and completely unacidulated $\mathrm{P}$ fertilisers in hill country.

The traditional small-plot mowing trial technique and the role of PAPR and RPR fertilisers in hill country both need re-evaluation.

\section{Acknowledgements}

Thanks to Ravensdown Fertiliser Co-operative Liited for the supply of fertiliser materials and a contribution to the application cost, to Venessa Pokaia, Des Costall and Phil Budding for technical assistance, the ladies in the herbage dissection laboratory, and Dr S. Wewala for statistical advice.

\section{REFERENCES}

Bray, R.H.; Kurtz, L.T. 1945. Determination of total, organic and available forms of phosphorus in soils. Soil Science 59: 39-45.
Gregg, P.E.H.; Mackay, A.D.; Cunie, L.D.; Syers, J.K. 1988. Application strategies for Sechura phosphate rock use on permanent pastures. Fertiliser Research 17: 219-234.

Gregg, P.E.H.; Mackay, A.D.; Tillman, R.W.; Currie, L.D. 1987. A summary of reactive phosphate rock research at Massey University. In The use of reactive phosphate rocks and their derivatives as fertilisers. (Eds R.E. White and L.D. Cunie), Occasional Report No. 1, Fertiliser and Lime Research Centre, Massey University, Palmerston North, New Zealand, 141-149.

Mackay, A.D.; Gregg, P.E.H.; Syers, J.K. 1984. Field evaluation of Chatham Rise phosphorite as a phosphatic fertiliser for pasture. NZ Journal of Agricultural Research 27: $65-82$.

Mackay, A.D.; Syers, J.K. 1985. Assessment of field techniques for evaluating phosphatic ferilisers in grazed hill country. Proceedings of 20th Technical Conference, New Zealand Fertiliser Manufacturers Research Association, Auckland, pp. 181-191.

Mackay, A.D.; Wewala, G.S. 1989. Evaluation of partially acidulated and phosphate fertilisers and reactive phosphate rock for hill pastures. Fertiliser Research 18 (in press).

Olsen, S.R.; Cole, C.V.; Watanabe, ES.; Dean, L.A. 1954. Estimation of available phosphorus in soils by extraction with sodium bicarbonate. USDA Cir 939 US Government Printing Office, Washington DC

Quin, B.F; Dyson, C.B.; Chiao, Y.S. 1987. Agronomic and economic aspects of the use of phosphate rocks for pasture - development of a predictive model. In The use of reactive phosphate rocks and their derivatives as fertilisers. (Eds R.E. White and L.D. Currie). Occasional Report No. 1, Fertiliser and Lime Research Centre, Massey University, Palmerston North, New Zealand, 147-163.

Rajan, S.S.S.; Quin, B.F. 1985. Partially acidulated phosphate rocks as phosphate fertilisers for pastures. Proceedings of 20th Technical Conference, New Zealand Feriliser Manufacturers Research Association, Auckland. pp. 411-423.

Rajan, S.S.S.; Gillingham, A.G.; O'Connor, M.B.; Percival, N.S.; Gray, M.G. 1987. Ground phosphate rocks as fertilisers for pastures. In The use of reactive phosphate rocks and their derivatives as fertiliser (Eds R.E. White and L.D. Currie). Occasional Report No. 1, Fertiliser and Lime Research Centre, Massey Universtiy, Palmerston North, New Zealand, 78-83. 